\title{
ARTICLE
}

\section{Discovery and enantiocontrol of axially chiral urazoles via organocatalytic tyrosine click reaction}

Ji-Wei Zhang ${ }^{1}$, Jin-Hui Xu', Dao-Juan Cheng ${ }^{1}$, Chuan Shi ${ }^{1}$, Xin-Yuan Liu ${ }^{1} \&$ Bin $\operatorname{Tan}^{1}$

Axially chiral compounds play an important role in areas such as asymmetric catalysis. The tyrosine click-like reaction is an efficient approach for synthesis of urazoles with potential applications in pharmaceutical and asymmetric catalysis. Here we discover a class of urazole with axial chirality by restricted rotation around an N-Ar bond. By using bifunctional organocatalyst, we successfully develop an organocatalytic asymmetric tyrosine click-like reaction in high yields with excellent enantioselectivity under mild reaction conditions. The excellent remote enantiocontrol of the strategy originates from the efficient discrimination of the two reactive sites in the triazoledione and transferring the stereochemical information of the catalyst into the axial chirality of urazoles at the remote position far from the reactive site.

\footnotetext{
${ }^{1}$ Department of Chemistry, South University of Science and Technology of China, Shenzhen 518055, China. Correspondence and requests for materials should be addressed to X.-Y.L. (email: liuxy3@sustc.edu.cn) or to B.T. (email: tanb@sustc.edu.cn).
} 
razoles are important heterocyclic compounds with potential pharmaceutical applications and valuable utilities in the area of protein modification chemistry due to the simplicity of chemical synthesis and ease of optimization of reaction conditions ${ }^{1-4}$. In addition, oxidation of urazoles gives rise to a very useful class of persistent cyclic hydrazyl radicals for versatile transformations ${ }^{5,6}$. Consequently, there is a large demand for easy access to a broad variety of these compounds. In this regard, the tyrosine click reaction provides a straightforward strategy to access such compounds under mild conditions as illustrated in Fig. 1a, in which a class of cyclic diazodicarboxamides (triazodiones) reacted selectively and rapidly with the phenol side chain of tyrosine as first developed by the Barbas group for the application in bioconjugate chemistry ${ }^{7,8}$. Although the development of other methodologies towards the synthesis of these compounds has also been reported $^{9-11}$, to the best of our knowledge, there is no any report involving the direct construction of chiral urazoles in a catalytic enantioselective manner. Inspired by a developing research field on atropisomeric compounds possessing an $\mathrm{N}-\mathrm{Ar}$ chiral axis ${ }^{12}$, we envisioned that urazoles directly obtained from tyrosine click-like reaction could be recognized as a type of axially chiral skeleton containing an $\mathrm{N}$-Ar chiral axis because of the presence of two N-Ar bonds in arylurazoles.

After discovery of the axially chiral urazoles (Fig. 1b, compound D), we turned our attention to construct the chiral urazoles in an atroposelective approach via tyrosine click-like reaction. In this scenario, three major challenges would be encountered: (1) the selection of suitable catalyst to interact with the substrates in high efficiency to inhibit the very strong background reaction; (2) the choice of an appropriate chiral catalyst prompt to efficiently induce remote axial enantiocontrol at the distant position via organocatalytic desymmetrization strategy ${ }^{13-19}$; (3) the use of mild reaction conditions to circumvent the axial rotation. Recently, some strategies have been successfully developed for the organocatalytic synthesis of axially chiral compounds ${ }^{20-33}$. Although the task of controlling the remote axial chirality under the current reaction system is a formidable challenge, the success of the above results provides strong evidence that organocatalysis can be performed in the control of axial chirality by using rationally designed substrate or catalyst. It is well known that bifunctional organocatalysts have made a great contribution to the field of asymmetric catalysis ${ }^{34-37}$. In such catalysts, the acidic and basic centres acting as both hydrogen-bonding donors and acceptors, respectively, thus activating the nucleophile and electrophile at the same time in an appropriate spatial configuration. As shown in Fig. 1c, we speculated that the utility of bifunctional organocatalysts could be expected by distinguishing the two nonequivalent reactive nitrogen centres $(a$ and $b$ ) in the triazoledione and transferring the central chirality of the catalyst into the axial chirality far from the reaction site. As part of our continued interest in the area of synthesis of axially chiral compounds ${ }^{38}$ and asymmetric catalysis $^{39}$, herein, we would like to exhibit the remote control of the axial chirality of arylurazoles by using a desymmetrization strategy via organocatalytic tyrosine click reaction of 4-aryl-1,2,4triazole-3,5-dione (ATAD). The key feature of our strategy is the ability of a bifunctional organocatalyst to transfer its

a<smiles>[R]c1ccc(O)cc1</smiles>

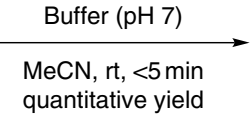<smiles>O=c1[nH]n(-c2cc(Br)ccc2O)c(=O)n1-c1ccccc1</smiles>

b

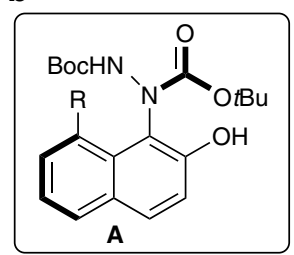

Jørgensen's discovery

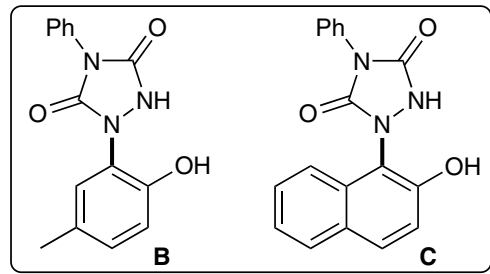

No axial chirality

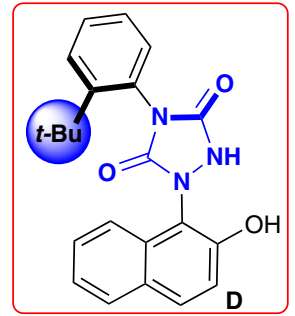

Our discovery of axially chiral urazoles

C
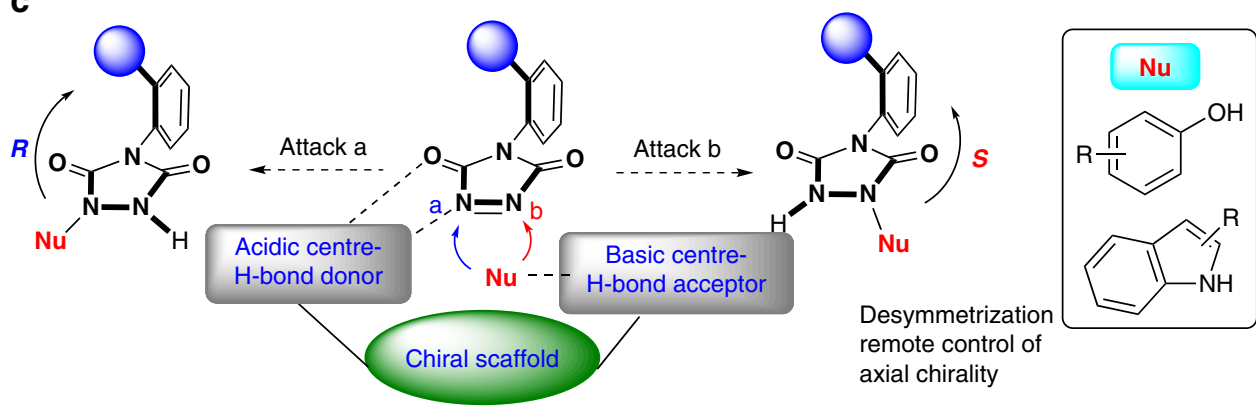
remote controlo chirality

Figure 1 | Synthesis of urazoles via tyrosine click reaction and discovery of axial chirality and strategy for remote enantiocontrol. (a) Synthesis of urazoles via tyrosine click reaction (Barbas' discovery). (b) Discovery of urazoles with axial chirality. (c) Our strategy for remote enantiocontrol of axial chirality of urazoles. 
stereochemical information to a remote position and thereafter efficiently control its axial chirality.

\section{Results}

Discovery of urazoles with axial chirality. In 2006, the Jørgensen group discovered a new class of axially chiral skeleton $\mathbf{A}$ via asymmetric amination of 8-amine-2-naphthol with azodicarboxylates (Fig. 1b) ${ }^{40,41}$. Motivated by this pioneering discovery, we synthesized the compounds B and $\mathbf{C}$ through tyrosine click reaction and imagined that such compounds should have axial chirality due to the significant restricted rotation between nitrogen atom and the directly attached phenol ring or naphthol ring (Fig. 1b). Disappointedly, they did not display axial chirality based on the chiral stationary high-performance liquid chromatography (HPLC) analysis presumably because of the relatively low rotational barrier of the $\mathrm{N}-\mathrm{Ar}$ bond. To further screen different aryl substituents of triazodiones, we are pleased to find that urazole $\mathbf{D}$ with a steric bulky substituent ( $t$-butyl group) in the ortho position of the phenyl ring shows apparently axial chirality. As such, a class of urazoles with axial chirality was discovered (Fig. 1b).

Optimization of reaction conditions involving naphthols. To investigate the feasibility of our hypothesis, we initiated to conduct the tyrosine click reaction of naphthol (1a) with 4-(2-tert-butylphenyl)-3H-1,2,4-triazole-3,5-dione (2a) by using

\section{Table 1 | Optimization of the organocatalytic enantioselective tyrosine click reaction ${ }^{\star}$.}<smiles>Oc1ccc2ccccc2c1</smiles>

$1 \mathrm{a}$<smiles>CC(C)(C)c1ccccc1N1C(=O)N=NC1=O</smiles>

2a<smiles>CC(C)(C)c1ccccc1-n1c(=O)[nH]n(-c2c(O)ccc3ccccc23)c1=O</smiles><smiles>CN(C)[C@H]1CCCC[C@H]1NC(=S)Nc1cc(C(F)(F)F)cc(C(F)(F)F)c1</smiles><smiles>CCCN(CCC)[C@@H]1CCCC[C@H]1NC(=S)N[C@@H](C(=O)NC)C(C)(C)C</smiles><smiles>CC[C@H]1CN2CCC1C[C@@H]2[C@H](NC(=S)Nc1cc(C(F)(F)F)cc(C(F)(F)F)c1)c1ccnc2ccc(OC)cc12</smiles><smiles>FC(F)(F)c1cc(NC(=S)N[C@H]2CCCC[C@H]2N2CCCCC2)cc(C(F)(F)F)c1</smiles><smiles>Cc1c(NC(=S)Nc2cc(C(F)(F)F)cc(C(F)(F)F)c2)ccc2ccccc12</smiles><smiles>CN(C)c1ccc2ccccc2c1</smiles><smiles>FC(F)(F)c1cc(NC(=S)NC2CCCCC2)cc(C(F)(F)F)c1</smiles><smiles>CC1CCCC[C@H]1NC(=S)Nc1cc(C(F)(F)F)cc(C(F)(F)F)c1</smiles><smiles>FC(F)(F)c1cc(NC(=S)NC(c2ccccc2)c2ccccc2)cc(C(F)(F)F)c1</smiles><smiles>c1ccc2c3c(ccc2c1)CNCc1ccc2ccccc2c1-3</smiles>

C6
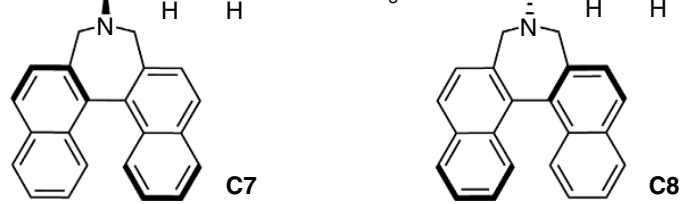

\begin{tabular}{|c|c|c|c|c|c|}
\hline Entry & Solvent & Catalyst & Time (min) & Yield (\%) ${ }^{\dagger}$ & ee $(\%)^{\ddagger}$ \\
\hline 1 & DCM & C1 & $<5$ & 57 & 25 \\
\hline 3 & DCM & C3 & $<5$ & 68 & 75 \\
\hline 5 & DCM & C5 & $<5$ & 63 & -9 \\
\hline 6 & DCM & C6 & $<5$ & 61 & -45 \\
\hline 7 & DCM & C7 & $<5$ & 68 & 91 \\
\hline 8 & DCM & C8 & $<5$ & 66 & -43 \\
\hline $17 \S$ & $\mathrm{Et}_{2} \mathrm{O}$ & $C 7$ & 30 & 82 & 99 \\
\hline $12^{\|}$ & $\mathrm{Et}_{2} \mathrm{O}$ & C7 & 90 & 70 & 98 \\
\hline
\end{tabular}

DCM, dichloromethane; HPLC, high-performance liquid chromatography.

${ }^{\star}$ Reactions were performed with $\mathbf{1 a}(0.10 \mathrm{mmol}), \mathbf{2 a}(0.12 \mathrm{mmol})$ and catalyst $(10 \mathrm{~mol} \%)$ in $2.0 \mathrm{ml}$ solvent

†lsolated yield.

$\ddagger$ Determined by HPLC analysis on a chiral stationary phase.

\$Reaction was conducted with $5 \mathrm{~mol} \%$ catalyst.

||3 mol\% catalyst was used. 
Takemoto catalyst $(\mathbf{C 1})^{42}$ in dichloromethane (DCM) at room temperature. To our delight, the desired product 3a was obtained in almost quantitative yield in less than $5 \mathrm{~min}$, albeit without any enantioselectivity. Using the analysis of chiral HPLC, the urazole compound 3a was confirmed to be atropisomeric and two peaks corresponding to the enantiomers were observed on the chiral HPLC at room temperature without any change during the analysis timescale. In the absence of organocatalyst, the reaction also proceeded very smoothly (less than $5 \mathrm{~min}$ for the model reaction) in quantitative yield, indicating that the strong background reaction might be the major challenge for efficiently realizing enantioselective transformation. With these initial results in hand and to improve the enantioselectivity, we turned our attention to decrease the reaction temperature to $-78^{\circ} \mathrm{C}$. Gratifyingly, the reaction proceeded completely within just $5 \mathrm{~min}$ and the desired product was obtained in $57 \%$ isolated yield with $25 \%$ enantioselectivity excess (ee). We next investigated different bifunctional thiourea-tertiary amine catalysts (Table 1, entries 2-5). Among the tested catalysts, Takemoto catalyst C3 with a cyclic tertiary amine proved to be very promising, with the ee value up to $75 \%$. Considering that the additional aromatic stacking interaction might be involved in the transition states, catalysts C6 and C7 with an axial binaphthyl moiety were tested $^{43}$. Catalyst C7 displayed an excellent enantiocontrol (entry 7 ), while catalyst $\mathbf{C 6}$ with opposite configuration of diamine gave rise to poor enantioselectivity (entry 6). As shown in entry 8 , the diamine skeleton in the catalyst had a great influence on the asymmetric induction. Of the solvents tested for the reaction catalysed by $\mathbf{C 7}$, diethyl ether proved optimal with respect to the enantioselectivity (Table 1, entry 10). It is noteworthy that the reaction proceeded smoothly without having any affect on enantioselectivity $(99 \%$ ee) and with an improved chemical yield up to $82 \%$ when $5 \mathrm{~mol} \%$ of catalyst was used (entry 11 ).

Substrate scope. After the optimal reaction condition being established, we set out to explore the substrate scope with respect to various phenols and 2-naphthnols as reactants (Table 2). All of the investigated reactions were complete within $60 \mathrm{~min}$ and gave products in moderate to good yields (51-85\%) and with excellent enantioselectivities $(90-99 \%$ ee). As regarding the use of a variety of 2-naphthols, bearing electron-withdrawing (Table 2, products $\mathbf{3 b} \mathbf{- 3 f}$ ) and electron-donating (Table 2, products $\mathbf{3 g}-\mathbf{3 h}$ ) groups, the reaction of these 2 -naphthols with 2 a gave the expected products with very high stereoselectivities. These results indicated that there was only limited influence on stereoselectivity regardless of the electronic properties of the substituents at the different positions on the aromatic ring. It is noteworthy that the use of 4-substituted phenol, such as 4-tert-butyl-phenol and 4-phenyl-phenol, also afforded the desired products $\mathbf{3} \mathbf{i}$ and $\mathbf{3} \mathbf{j}$ in excellent stereocontrol with a modified reaction conditions, respectively, demonstrating that the substrate scope could not be only limited to naphthols.

Table 2 | Substrate scope of naphthols or phenols ${ }^{\star}$.
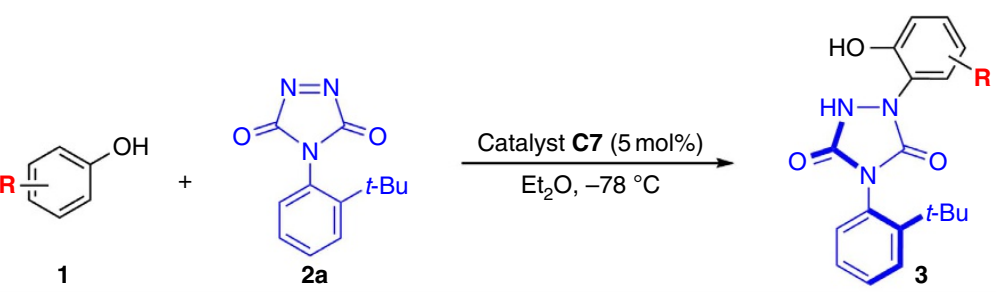<smiles>CC(C)(C)c1ccccc1-n1c(=O)[nH]n(-c2c(O)ccc3ccccc23)c1=O</smiles>

$30 \mathrm{~min}$,

$82 \%$ Yield, $99 \%$ ee<smiles>Cc1ccc(-c2ccc3ccc(O)c(-n4[nH]c(=O)n(-c5ccccc5C(C)(C)C)c4=O)c3c2)cc1</smiles>

$60 \mathrm{~min}$,

$71 \%$ Yield, $99 \%$ ee<smiles>CC(C)(C)c1ccccc1-n1c(=O)[nH]n(-c2c(O)ccc3ccc(Br)cc23)c1=O</smiles>

$15 \mathrm{~min}$, $85 \%$ Yield $99 \%$ ee

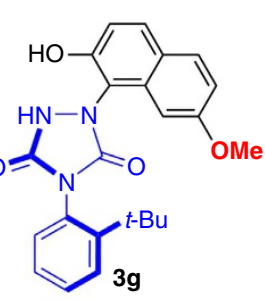

$30 \mathrm{~min}$,

$81 \%$ Yield $97 \%$ ee
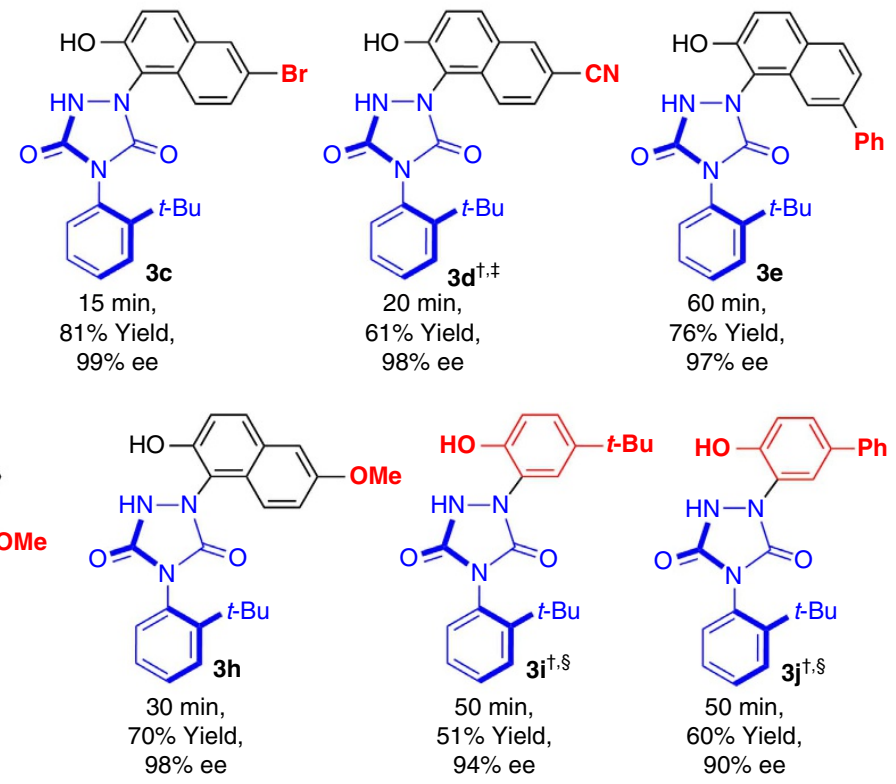

DCM, dichloromethane; HPLC, high-performance liquid chromatography.

${ }^{*}$ Reactions were performed with $\mathbf{1}(0.1 \mathrm{mmol}), \mathbf{2 a}(0.12 \mathrm{mmol})$ and catalyst $\mathbf{C 7}(5 \mathrm{~mol} \%)$ in $2.0 \mathrm{ml} \mathrm{Et}{ }_{2} \mathrm{O}$. Isolated yields and the ee values were determined with $\mathrm{HPLC}$ analysis using the chiral stationary phase.

†Reactions were performed with $20 \mathrm{~mol} \%$ catalyst $\mathbf{C 7}$ in $2.0 \mathrm{ml}$ solvent.

$\ddagger$ In DCM at $-78^{\circ} \mathrm{C}$

$\S$ In toluene at $-40^{\circ} \mathrm{C}$ 
Next, we explored the generality of the reaction with regard to variation of ATADs. A broad range of ATADs containing different substituents at the aromatic ring reacted smoothly with 2-naphthol 1a to produce the corresponding axially chiral urazoles with high efficiency and excellent entantiocontrol (Table 3). The electronic and position properties of the aromatic ring substituents did not affect the selectivities of the tyrosine click reactions. It should be pointed out that the ortho group is not only restricted to tert-butyl group or iodo, and the bromo or phenyl group at the ortho position could also be obtained with excellent enantioselectivities (3p and $\mathbf{3 q}$ ). It should be emphasized that the presence of $\mathrm{I}$ or $\mathrm{Br}$ is very convinient to do the further transformation for diversity-oriented synthesis and drug discovery due to the high reactivity in many transition metalcatalysed reactions ${ }^{44}$. Experiments on the configurational stability of the product were carried out by heating a solution of $3 \mathbf{a}$ in toluene or $\mathrm{MeCN}$ at $80^{\circ} \mathrm{C}$ for $12 \mathrm{~h}$. Chiral HPLC analysis showed that the ee value of $\mathbf{3 a}$ did not have any effect. Therefore, the obtained axially chiral compounds may have potential wide applications as asymmetric organocatalysts/ligands.

Optimization of reaction conditions involving indoles. To expand the synthetic utility of this methodology and further develop the application of the very reactive ATAD, we next focused our attention on more challenging nucleophiles. Although much progress has been made in the development of organocatalytic asymmetric intermolecular transformation by using indoles as nucleophiles ${ }^{45,46}$, to the best of our knowledge, only few examples involving 2-substituted indoles as nucleophile have been reported with good enantiocontrol, which is probably ascribed to the interrupted interaction between the substrates and the organocatalyst ${ }^{47}$. We envisaged that the very reactive and multifunctional electrophile ATAD might provide new possibility to proceed such a remote control process with good stereoselectivity with bifunctional organocatalysts. To our delight, by using the standard reaction conditions (Table 4, entry 1), we found that the reaction of 2 -phenylindole $\mathbf{4 a}$ with 4-(2-tert-butylphenyl)-3H-1,2,4-triazole-3,5-dione (2a) proceeded smoothly by simply using the catalyst $\mathbf{C 6}$, giving the desired product $5 \mathrm{a}$ in $74 \%$ yield with $15 \%$ ee. However, after making great efforts on investigation of the optimized reaction conditions, we could not improve the enantioselectivity by using thioureatertiary amine organocatalyst (see Supplementary Table 1 for details). On the basis of these findings and own comprehension on the phosphoric acid catalysis ${ }^{48-50}$, we envisioned that phosphoric acid might perform bifunctional action to activate indole and ATAD simutaneously and control the enantioselectivity ${ }^{51-54}$. As shown in Table 4, phosphoric acid

Table 3 | The reaction substrate scope of 4-aryl-1,2,4-triazoline-3,5-diones ${ }^{\star}$.<smiles>Oc1ccc2ccccc2c1</smiles>

1a<smiles>CC(C)(C)c1cc(Br)ccc1-n1c(=O)[nH]n(-c2c(O)ccc3ccccc23)c1=O</smiles><smiles>Cc1cccc(I)c1-n1c(=O)[nH]n(-c2c(O)ccc3ccccc23)c1=O</smiles>

$90 \mathrm{~min}$, $70 \%$ Yield $98 \%$ ee<smiles>CC(C)(C)c1cc(-c2ccccc2)ccc1-n1c(=O)[nH]n(-c2c(O)ccc3ccccc23)c1=O</smiles><smiles>Cc1cc(C)c(-n2c(=O)[nH]n(-c3c(O)ccc4ccccc34)c2=O)c(I)c1</smiles><smiles>Cc1cccc(Br)c1-n1c(=O)[nH]n(-c2c(O)ccc3ccccc23)c1=O</smiles>

$60 \mathrm{~min}$, $70 \%$ Yield, $93 \%$ ee<smiles>Cc1cccc(-c2ccccc2)c1-n1c(=O)[nH]n(-c2c(O)ccc3ccccc23)c1=O</smiles>

$60 \mathrm{~min}$, $73 \%$ Yield $95 \%$ ee<smiles></smiles><smiles>Cc1cc(Br)cc(I)c1-n1c(=O)[nH]n(-c2c(O)ccc3ccccc23)c1=O</smiles>

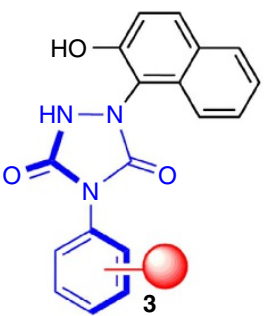<smiles>O=c1[nH]c(=O)n(-c2c(O)ccc3ccccc23)[nH]1</smiles><smiles>Cc1c(I)cc(Br)c2ccccc12</smiles>

HPLC, high-performance liquid chromatography.

${ }^{\star}$ Reactions were performed with $\mathbf{1 a}(0.1 \mathrm{mmol}), \mathbf{2}(0.12 \mathrm{mmol})$ and catalyst $\mathbf{C 7}(5 \mathrm{~mol} \%)$ in $2.0 \mathrm{ml} \mathrm{Et}_{2} \mathrm{O}$. Isolated product and the ee values were determined by $\mathrm{HPLC}$ analysis using a chiral stationary phase. 
Table 4 | Optimization of the asymmetric tyrosine click-like reaction involving indoles as nucleophiles ${ }^{\star}$.

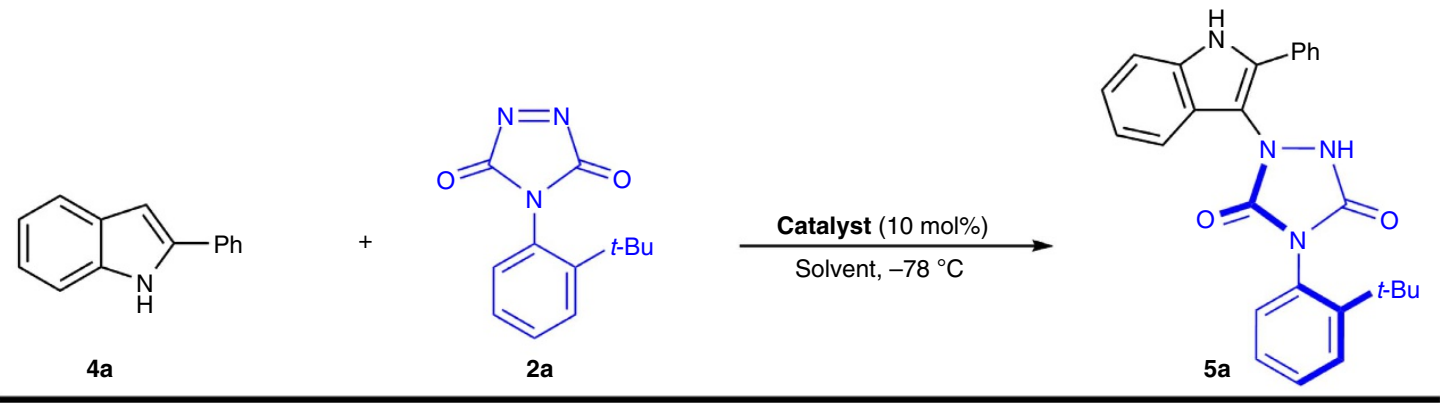<smiles>C[C@@]12CCC3=CC=C(Br)C3=C1P(=O)(O)Oc1c(Br)ccc(Br)c12</smiles>

CP1, Ar = 1-naphthyl

CP2, Ar = 1-pyrenyl

CP3, $\mathrm{Ar}=3,5-\left(\mathrm{CF}_{3}\right)_{2}-\mathrm{C}_{6} \mathrm{H}_{3}$

CP4, Ar = 1,1'-biphenyl-4-yl

CP5, Ar = 9-phenanthyl<smiles>O=P(O)(O)Oc1c(Br)cc2ccccc2c1-c1c(Br)cc2ccccc2c1Br</smiles>

CP6, Ar = 1-naphthyl

CP7, $\operatorname{Ar}=\left(1,1^{\prime}\right.$-biphenyl)-4-yl

CP8, $\mathrm{Ar}=$ 2,4,6-triisopropylphenyl

CP9, $\mathrm{Ar}=$ 9-phenanthyl<smiles>O=P1(O)OC2=C(c3c4c(cc(OC(F)(F)F)c3O1)CCCC4)C1CCCCC1C=C2O</smiles>

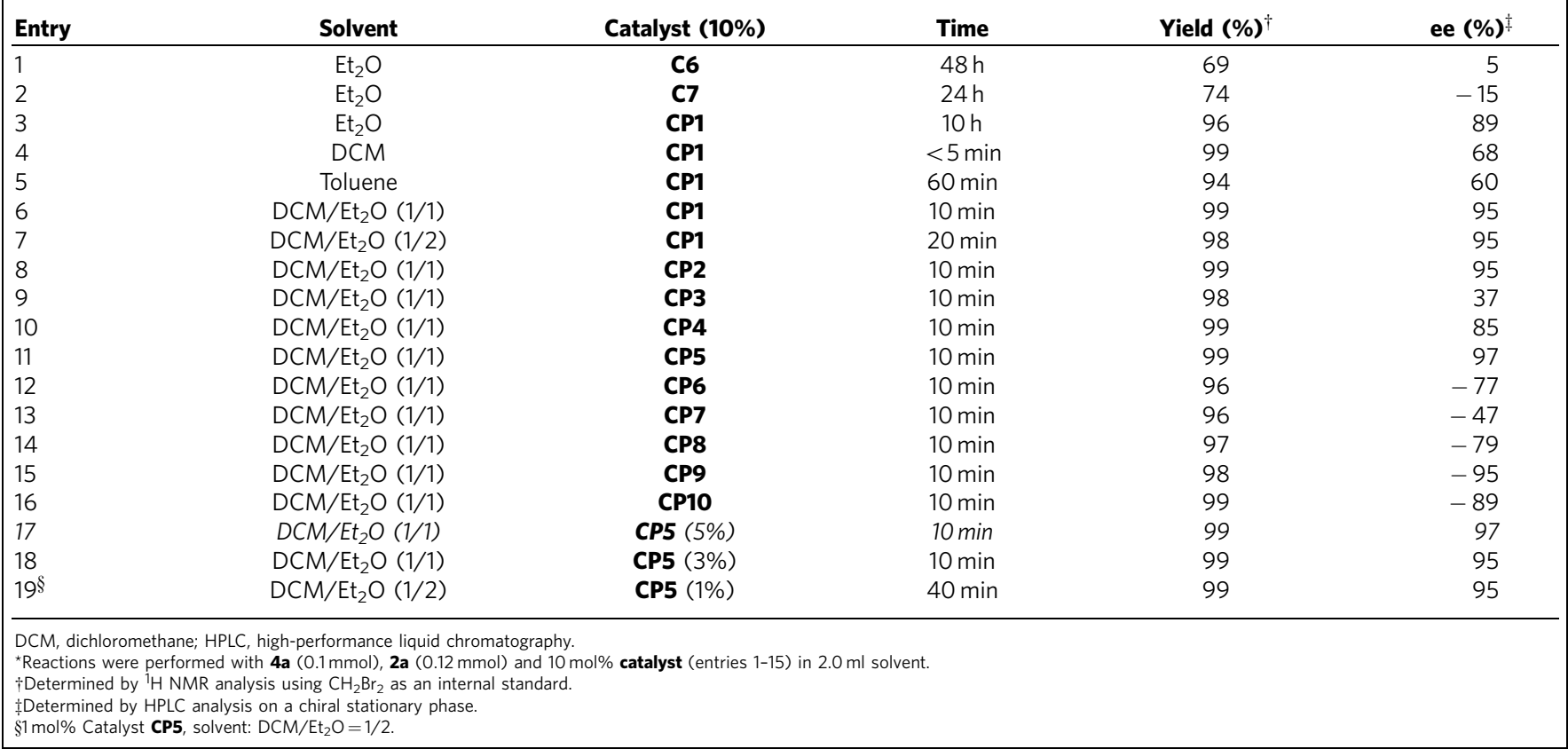

catalyst proved to be a suitable organocatalyst for this tranformation. On optimizing the reaction conditions through variation of the phosphoric acid catalysts, solvents and catalyst loadings (Table 4, entries 3-15), the following protocol was proved to be optimal: reaction of $\mathbf{4 a}$ and $\mathbf{2 a}$ with the molar ratio of 1.0:1.2 by using phosphoric acid CP5 $(5 \mathrm{~mol} \%)$ as catalyst in $\mathrm{DCM} / \mathrm{Et}_{2} \mathrm{O}(1 / 1)$ at $-78^{\circ} \mathrm{C}$ for $10 \mathrm{~min}, 5 \mathbf{a}$ was obtained in exellent yield with $97 \%$ ee (Table 4 , entry 15 ). It should be noted that the chiral spiro-phosphoric acid catalyst displayed better enantioselectivity than the BINOL-derived catalyst if the substituent in the 3 and $3^{\prime}$ positions is the same (entries 6 and 12; entries 10 and 13; entries 11 and 15).
Substrate scope with indoles as nucleophiles. Having identified the optimized reaction conditions, the reaction was extended to include various 2-substituted indoles and triazoledione compounds with catalyst CP5. As shown in Table 5, the reaction proceeded smoothly to give the desired product $\mathbf{5 a}-\mathbf{5 m}$ in very high yield (86-96\%) and excellent enantioselectivity (84-97\% ee). It should be noted that the electronic nature, bulkiness or positions of the substituents on the cyclic diazo compounds and substituted indoles have only minimal effect on efficiencies and enantioselectivities. In addition to aromatic groups, alkyl substituents on indole were used to acquire the desired products $(\mathbf{5 l}$ and $\mathbf{5 m})$ with excellent yields and 
Table 5 | The substrate scope by using indoles as nucleophiles`.<smiles>[R]c1ccc(N2C(=O)N=NC2=O)c(C(C)(C)C)c1</smiles>

4

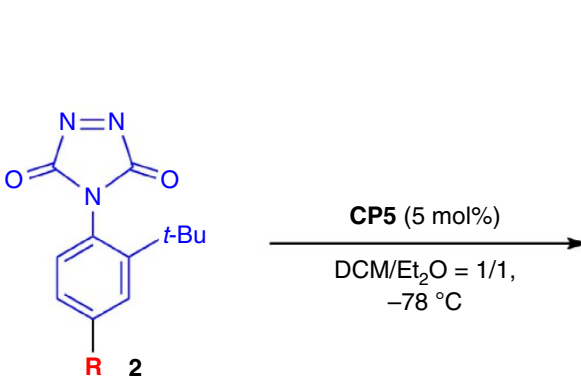<smiles></smiles>

\begin{tabular}{|c|c|c|c|c|c|c|c|}
\hline Entry & $\mathbf{R}$ & $\mathbf{R}^{1}$ & $\mathbf{R}^{2}$ & Time (min) & 5 & Yield $(\%)^{\dagger}$ & ee $(\%)^{\ddagger}$ \\
\hline 1 & $\mathrm{H}$ & $\mathrm{Ph}$ & $\mathrm{H}$ & 10 & $5 a$ & 96 & 97 \\
\hline 2 & $\mathrm{H}$ & 4-F-Ph & $\mathrm{H}$ & 15 & $5 b$ & 95 & 96 \\
\hline 3 & $\mathrm{H}$ & 4-Cl-Ph & $\mathrm{H}$ & 20 & $5 c$ & 95 & 92 \\
\hline 4 & $\mathrm{H}$ & $\mathrm{Ph}$ & $\mathrm{Br}$ & 15 & $5 d$ & 94 & 94 \\
\hline 5 & $\mathrm{H}$ & $\mathrm{Ph}$ & $\mathrm{Ph}$ & 15 & $5 e$ & 90 & 96 \\
\hline 6 & $\mathrm{Br}$ & $\mathrm{Ph}$ & $\mathrm{H}$ & 10 & $5 f$ & 92 & 93 \\
\hline 7 & $\mathrm{Br}$ & 4-F-Ph & $\mathrm{H}$ & 15 & $5 g$ & 92 & 93 \\
\hline 8 & $\mathrm{Br}$ & 4-Cl-Ph & $\mathrm{H}$ & 20 & $5 h$ & 93 & 91 \\
\hline 9 & $\mathrm{Ph}$ & $\mathrm{Ph}$ & $\mathrm{H}$ & 10 & $5 \mathbf{i}$ & 92 & 94 \\
\hline 10 & $\mathrm{Ph}$ & 4-F-Ph & $\mathrm{H}$ & 20 & $5 \mathbf{j}$ & 91 & 95 \\
\hline 11 & $\mathrm{Ph}$ & 4-Cl-Ph & $\mathrm{H}$ & 20 & $5 k$ & 86 & 92 \\
\hline 12 & $\mathrm{H}$ & Isopropyl & $\mathrm{H}$ & $<5$ & 51 & 95 & 90 \\
\hline 13 & $\mathrm{H}$ & Methyl & $\mathrm{H}$ & $<5$ & $5 m$ & 95 & 84 \\
\hline
\end{tabular}

DCM, dichloromethane; HPLC, high-performance liquid chromatography.

*Reactions were performed with $\mathbf{2}(0.12 \mathrm{mmol}), \mathbf{4}(0.10 \mathrm{mmol})$ and catalyst $\mathbf{C P 5}(5 \% \mathrm{mmol})$ in $2.0 \mathrm{ml}$ solvent $\left(\mathrm{DCM} / \mathrm{Et}_{2} \mathrm{O}=1 / 1\right)$.

†lsolated yield.

$\ddagger$ The ee values were determined by HPLC analysis using a chiral stationary phase.

good stereoselectivities in just less than 5 min (Table 5, entries $12-13)$.

Preliminary evaluation as chiral ligands. To verify the stability of such axial compounds, we heated the obtained product $\mathbf{5 a}$ in $\mathrm{MeCN}$ at $80^{\circ} \mathrm{C}$ for $12 \mathrm{~h}$ and no ee erosion was observed. Thus, this kind of axially chiral compounds displayed a high rotation energy about the $\mathrm{N}-\mathrm{Ar}$ bond, indicating that the chiral urazoles may have potential applications in the field of asymmetric organocatalysts and Lewis acid catalysis. To really investigate the potential application of the resultant axially chiral urazoles in the field of asymmetric catalysis, we chose the addition of $\mathrm{N}$-methylindole (8) to $\mathrm{N}$-methylisatin (9) as a model reaction and evaluated the potential application in the asymmetric catalysis (see Supplementary Table 2). Gratifyingly, the reaction proceeded completely within $8 \mathrm{~h}$ at $5^{\circ} \mathrm{C}$ and the desired product (10) was obtained in $96 \%$ yield with $62 \%$ ee (Fig. 2a), demonstrating that the newly developed axially chiral urazoles have the potential application in asymmetric synthesis. Further work encompassing the application of axially chiral urazoles as ligands or catalysts for enantioselective reactions is currently in progress in our laboratory.

Gram-scale synthesis of enantiopure urazoles. To further demonstrate the utility of the tyrosine click-like reaction, gramscale syntheses of products $\mathbf{3 a}$ and $\mathbf{5 a}$ were carried out. As displayed in Fig. 2b, there was almost no change in reactivity and stereoselectivity, suggesting that this method should have the potential for large-scale chemical production (also see Supplementary Note 3). It should be worth highlighting that the reaction by using 2-phenyl indole as nucleophile was proceeded very smoothly, with only $1 \mathrm{~mol} \%$ of phosphoric acid catalyst CP5. The absolute configuration of $\mathbf{3 p}$ was attributed to be $a S$ and $\mathbf{5 f}$ was assigned to be $a R$ using X-ray diffraction analysis of their methylation derivatives $\mathbf{6 p}$ and $7 \mathbf{f}$ (Fig. 2c, see also Supplementary Fig. 1).

\section{Discussion}

We have successfully developed an organocatalytic asymmetric tyrosine click-like reaction in high yields with excellent enantioselectivity under mild reaction conditions in an excellent remote enantiocontrol manner. The reaction represents a very convenient approach to an interesting class of axially chiral urazole derivatives, with potential biological activities and potential application as effective chiral organocatalysts/ligands. The excellent remote enantiocontrol of the process stems from the efficient discrimination of the two reactive sites in the triazoledione-involving phenols or indoles as nucleophile and transferring the chirality of the catalyst into the axial chirality of urazoles at the remote position far from the reactive site. The application of this strategy to a broader substrate scope and mechanistic investigations of the desymmetrization strategy are currently underway in our group.

\section{Methods}

General information. Reagents were purchased at the highest commercial quality and used without further purification, unless otherwise stated. Analytical thin layer chromatography (TLC) was performed on precoated silica gel 60 F254 plates. Flash column chromatography was performed using Tsingdao silica gel (60, particle size $0.040-0.063 \mathrm{~mm}$ ). Visualization on TLC was achieved by the use of ultraviolet light $(254 \mathrm{~nm})$. NMR spectra were recorded on a Bruker DPX 400 spectrometer at $400 \mathrm{MHz}$ for ${ }^{1} \mathrm{H}$ NMR, $100 \mathrm{MHz}$ for ${ }^{13} \mathrm{C}$ NMR and $376 \mathrm{MHz}$ for ${ }^{19} \mathrm{~F} \mathrm{NMR}$ in $\mathrm{CDCl}_{3}$ or acetone- $d_{6}$ with tetramethylsilane as internal standard. Chemical shifts are reported in p.p.m., and coupling constants are given in $\mathrm{Hz}$. 
a<smiles>CN1C(=O)C(=O)c2ccccc21</smiles><smiles>CN1C(=O)C(O)(c2cn(C)c3ccccc23)c2ccccc21</smiles><smiles>CC(C)(C)c1ccccc1-n1c(=O)[nH]n(-c2c(O)ccc3ccccc23)c1=O</smiles>

\section{b}

10<smiles>CC(C)(C)c1ccccc1-n1c(=O)[nH]n(-c2c(-c3ccccc3)[nH]c3ccccc23)c1=O</smiles><smiles>c1ccc(-c2cc3ccccc3[nH]2)cc1</smiles>

4a $\mathrm{H}$

$1.22 \mathrm{~g}, 96 \%$ $95 \%$ ee<smiles>CC(C)(C)c1ccccc1N1C(=O)N=NC1=O</smiles>

2a<smiles></smiles>

C7 (5 mol\%)

$\mathrm{Et}_{2} \mathrm{O},-78^{\circ} \mathrm{C}$ $4 \mathrm{~h}$

1a $(3.2 \mathrm{mmol})$ 2a $(3.8 \mathrm{mmol})$ 4a $(3.0 \mathrm{mmol})$
$2 \mathrm{a}(3.6 \mathrm{mmol})$

CP5 (1 mol\%)

$\mathrm{DCM} / \mathrm{Et}_{2} \mathrm{O}=1 / 2$
$-78^{\circ} \mathrm{C}, 40 \mathrm{~min}$

c<smiles>Cc1cccc(Br)c1-n1c(=O)[nH]n(-c2c(O)ccc3ccccc23)c1=O</smiles>

3p (93\% ee)

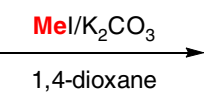<smiles>COc1ccc2ccccc2c1-n1c(=O)n(-c2c(C)cccc2Br)c(=O)n1C</smiles>

$6 p(91 \%$ ee)<smiles>C/C=C\C(=O)OC(C)(C)C(C)(C)C</smiles><smiles>CNNc1c(-c2ccccc2)n(C)c2ccccc12</smiles><smiles>O=c1[nH][nH]c(=O)[nH]1</smiles><smiles>CC(C)(C)c1cc(Br)ccc1N</smiles>

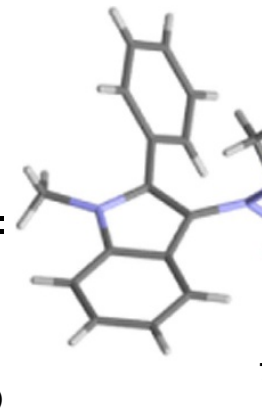

$6 p$<smiles>CC(C)(C)c1ccccc1-n1c(=O)[nH]n(-c2c(O)ccc3ccccc23)c1=O</smiles>

$1.02 \mathrm{~g}, 85 \%$ $98 \%$ ee

Figure 2 | Application in asymmetric catalysis and gram-scale synthesis of 3a/5a and further transformation. (a) Potential application of catalytic asymmetric synthesis of substituted 3-hydroxy-2-oxindole. (b) Gram-scale synthesis of axially chiral urazoles via tyrosine click reaction. (c) Further transformation for confirmation of absolute configuration.

Data for ${ }^{1} \mathrm{H}$ NMR are recorded as follows: chemical shift (p.p.m.), multiplicity (s, singlet; d, doublet; t, triplet; q, quartet; $\mathrm{m}$, multiplet), coupling constant $(\mathrm{Hz})$ and integration. Data for ${ }^{13} \mathrm{C}$ NMR are reported in terms of chemical shift $(\delta$, p.p.m.). High-resolution mass spectra were recorded on a LC-TOF spectrometer (Micromass). Enantiomeric excess was determined on Agilent HPLC using the DAICEL CHIRAL column. For preparation of 4-aryl-1,2,4triazoline-3,5-diones, see Supplementary Note 1.

Racemic compounds were obtained without catalyst.

General procedure for synthesis of axially chiral urazoles 3. In a Schlenk tube, 4-aryl-1,2,4-triazoline-3,5-diones $2(0.12 \mathrm{mmol})$ and catalyst $\mathbf{C} 7(5 \mathrm{~mol} \%$, $0.005 \mathrm{mmol}$ ) were dissolved in $\mathrm{Et}_{2} \mathrm{O}(2 \mathrm{ml}$; also see Supplementary Note 2). The solution was stirred for $10 \mathrm{~min}$ at $-78^{\circ} \mathrm{C}$ before 2-naphthols and phenols 1 $(0.10 \mathrm{mmol})$ were added. The resulting solution was stirred at $-78^{\circ} \mathrm{C}$ until the red colour disappeared. After monitored with TLC, the reaction mixture was acidified with $6 \mathrm{~N} \mathrm{HCl}$ and concentrated. Then, the obtained crude material was purified using silica gel column chromatography $\left(\mathrm{CH}_{2} \mathrm{Cl}_{2}\right.$ to $\left.\mathrm{CH}_{2} \mathrm{Cl}_{2} / \mathrm{Acetone}=10 / 1\right)$ to afford the pure products 3 . In some cases, reactions were performed with $20 \mathrm{~mol} \%$ of catalyst $\mathbf{C} 7$ in $2.0 \mathrm{ml}$ solvent, for $\mathbf{3} \mathbf{d}$ in DCM at $-78^{\circ} \mathrm{C} ; \mathbf{3 i}$ and $\mathbf{3} \mathbf{j}$ in dry toluene at $-40{ }^{\circ} \mathrm{C}$

General procedure for synthesis of axially chiral urazoles 5. In a Schlenk tube, 4-aryl-1,2,4-triazoline-3,5-diones $2(0.12 \mathrm{mmol})$ and catalyst $\mathbf{C P 5}(5 \mathrm{~mol} \%$, $0.005 \mathrm{mmol})$ were dissolved in $\mathrm{DCM} / \mathrm{Et}_{2} \mathrm{O}=1 / 1(2 \mathrm{ml}$; also see Supplementary Note 2). The solution was stirred for $10 \mathrm{~min}$ at $-78^{\circ} \mathrm{C}$ before 2-substituted indole $4(0.10 \mathrm{mmol})$ was added. The resulting solution was stirred under this condition until the purple colour disappeared. After being monitored with TLC, the reaction mixture was concentrated, and then purified using silica gel column chromatography $\left(\mathrm{CH}_{2} \mathrm{Cl}_{2} /\right.$ Acetone $\left.=20 / 1\right)$ to afford the pure products 5 .

\section{References}

1. Hall, I. H., Wong, O. T., Simlot, S., Miller, III. M. C. \& Izydore, R. A. Antineoplastic activities and cytotoxicity of 1-acyl and 1,2-diacyl-1,2,4triazolidine-3,5-diones in murine and human tissue culture cells. Anticancer Res. 12, 1355-1362 (1992). 
2. Martinez, A. et al. SAR and 3D-QSAR studies on thiadiazolidinone derivatives: exploration of structural requirements for glycogen synthase Kinase 3 inhibitors. J. Med. Chem. 48, 7103-7112 (2005).

3. Adibia, H., Abirib, R., Mallakpourc, S., Zolfigold, M. A. \& Majnoonie, M. B. Evaluation of in vitro antimicrobial and antioxidant activities of 4-substituted1,2,4-triazolidine-3,5-dione derivatives. J. Rep. Pharm. Sci. 1, 87-93 (2012).

4. Saluja, P., Khurana, J. M., Nikhilb, K. \& Royb, P. Task-specific ionic liquid catalyzed synthesis of novel naphthoquinone-urazole hybrids and evaluation of their antioxidant and in vitro anticancer activity. RSC Adv. 4, 34594-34603 (2014).

5. Pirkle, W. H. \& Gravel, P. L. Persistent cyclic diacylhydrazyl radicals from urazoles and pyrazolidine-3,5-diones. J. Org. Chem. 43, 808-815 (1978).

6. Breton, G. W. \& Hoke, K. R. Application of radical cation spin density maps toward the prediction of photochemical reactivity between N-methyl-1,2,4triazoline-3,5-dione and substituted benzenes. J. Org. Chem. 78, 4697-4707 (2013).

7. Ban, H., Gavrilyuk, J. \& Barbas, C. F. III Tyrosine bioconjugation through aqueous ene-type reactions: a click-like reaction for tyrosine. J. Am. Chem. Soc. 132, 1523-1525 (2010).

8. Ban, H. et al. Facile and stabile linkages through tyrosine: bioconjugation strategies with the tyrosine-click reaction. Bioconjug. Chem. 24, 520-532 (2013).

9. Alajarin, M., Cabrera, J., Sanchez-Andrada, P., Orenes, R. \& Pastor, A. 4-Alkenyl-2-aminothiazoles: smart dienes for polar $[4+2]$ cycloadditions. Eur. J. Org. Chem. 2013, 474-489 (2013).

10. Breton, G. W. Acid-catalyzed reactions of N-methyl-1,2,4-triazoline-3,5-dione (METAD) with some polyaromatic hydrocarbons. Adv. Chem. Lett. 1, 68-73 (2013).

11. Breton, G. W., Hughes, J. S., Pitchko, T. J., Martin, K. L. \& Hardcastle, K. Unexpected $\sigma$ bond rupture during the reaction of $\mathrm{N}$-methyl-1,2,4-triazoline3,5-dione with acenaphthylene and indene. J. Org. Chem. 79, 8212-8220 (2014).

12. Takahashi, I., Suzuki, Y. \& Kitagawa, O. Asymmetric synthesis of atropisomeric compounds with an N-C chiral axis. Org. Prep. Proced. Int. 46, 1-23 (2014).

13. Díaz de Villegas, M. D., Gálvez, J. A., Etayo, P., Badorrey, R. \& López-Ramde-Víu, P. Recent advances in enantioselective organocatalyzed anhydride desymmetrization and its application to the synthesis of valuable enantiopure compounds. Chem. Soc. Rev. 40, 5564-5587 (2011).

14. Rubush, D. M., Morges, M. A., Rose, B. J., Thamm, D. H. \& Rovis, T. An asymmetric synthesis of 1,2,4-trioxane anticancer agents via desymmetrization of peroxyquinols through a brønsted acid catalysis cascade. J. Am. Chem. Soc. 134, 13554-13557 (2012).

15. Wang, Z., Chen, Z. \& Sun, J. Catalytic enantioselective intermolecular desymmetrization of 3-substituted oxetanes. Angew. Chem. Int. Ed. 52, 6685-6688 (2013).

16. Wang, Z. et al. Catalytic enantioselective intermolecular desymmetrization of azetidines. J. Am. Chem. Soc. 137, 5895-5898 (2015).

17. Meng, S.-S. et al. Chiral phosphoric acid catalyzed highly enantioselective desymmetrization of 2-substituted and 2,2-disubstituted 1,3-diols via oxidative cleavage of benzylidene acetals. J. Am. Chem. Soc. 136, 12249-12252 (2014).

18. Gualtierotti, J.-B., Pasche, D., Wang, Q. \& Zhu, J. Phosphoric acid catalyzed desymmetrization of bicyclic bislactones bearing an all-carbon stereogenic center: total syntheses of (-)-Rhazinilam and (-)-Leucomidine B. Angew. Chem. Int. Ed. 53, 9926-9930 (2014).

19. Iorio, N. D. et al. Remote control of axial chirality: aminocatalytic desymmetrization of $\mathrm{N}$-arylmaleimides via vinylogous Michael addition. J. Am. Chem. Soc. 136, 10250-10253 (2014).

20. Miyaji, R., Asano, K. \& Matsubara, S. Bifunctional organocatalysts for the enantioselective synthesis of axially chiral isoquinoline N-Oxides. J. Am. Chem. Soc. 137, 6766-6769 (2015).

21. Armstrong, R. J. \& Smith, M. D. Catalytic enantioselective synthesis of atropisomeric biaryls: a cation-directed nucleophilic aromatic substitution reaction. Angew. Chem. Int. Ed. 53, 12822-12826 (2014).

22. Li, G.-Q. et al. Organocatalytic aryl-aryl bond formation: an atroposelective $[3,3]$-rearrangement approach to BINAM derivatives. J. Am. Chem. Soc. 135, 7414-7417 (2013).

23. De, C. K., Pesciaioli, F. \& List, B. Catalytic asymmetric benzidine rearrangement. Angew. Chem. Int. Ed. 52, 9293-9295 (2013).

24. Gustafson, J. L., Lim, D. \& Miller, S. J. Dynamic kinetic resolution of biaryl atropisomers via peptide-catalyzed asymmetric bromination. Science 328, 1251-1255 (2010).

25. Barrett, K. T. \& Miller, S. J. Enantioselective synthesis of atropisomeric benzamides through peptide-catalyzed bromination. J. Am. Chem. Soc. 135, 2963-2966 (2013).

26. Barrett, K. T., Metrano, A. J., Rablen, P. R. \& Miller, S. J. Spontaneous transfer of chirality in an atropisomerically enriched two-axis system. Nature 509, $71-75$ (2014).

27. Cozzi, P. G., Emer, E. \& Gualandi, A. Atroposelective organocatalysis. Angew. Chem. Int. Ed. 50, 3847-3849 (2011).
28. Shirakawa, S., Liu, K. \& Maruoka, K. Catalytic asymmetric synthesis of axially chiral o-iodoanilides by phase-transfer catalyzed alkylations. J. Am. Chem. Soc. 134, 916-919 (2012).

29. Shirakawa, S., Wu, X. \& Maruoka, K. Kinetic resolution of axially chiral 2-amino-1,1'-biaryls by phase-transfer-catalyzed N-allylation. Angew. Chem. Int. Ed. 52, 14200-14203 (2013).

30. Lu, S., Poh, S. B. \& Zhao, Y. Kinetic resolution of 1,1'-biaryl-2,2'-diols and amino alcohols through NHC-catalyzed atroposelective acylation. Angew. Chem. Int. Ed. 53, 11041-11045 (2014).

31. Ma, G., Deng, J. \& Sibi, M. P. Fluxionally chiral DMAP catalysts: kinetic resolution of axially chiral biaryl compounds. Angew. Chem. Int. Ed. 53, 11818-11821 (2014).

32. Mori, K. et al. Enantioselective synthesis of multisubstituted biaryl skeleton by chiral phosphoric acid catalyzed desymmetrization/kinetic resolution sequence. J. Am. Chem. Soc. 135, 3964-3970 (2013).

33. Link, A. \& Sparr, C. Organocatalytic atroposelective aldol condensation: synthesis of axially chiral biaryls by arene formation. Angew. Chem. Int. Ed. 53, 5458-5461 (2014).

34. Akiyama., T. Stronger Brønsted acids. Chem. Rev. 107, 5744-5758 (2007).

35. Okino, T., Hoashi, Y., Furukawa, T., Xu, X. \& Takemoto, Y. Enantio- and diastereoselective Michael reaction of 1,3-dicarbonyl compounds to nitroolefins catalyzed by a bifunctional thiourea. J. Am. Chem. Soc. 127, 119-125 (2005).

36. Siau, W.-Y. \& Wang, J. Asymmetric organocatalytic reactions by bifunctional amine-thioureas. Catal. Sci. Technol. 1, 1298-1310 (2011).

37. Chauhan, P., Mahajan, S., Kaya, U., Hack, D. \& Enders, D. Bifunctional aminesquaramides: powerful hydrogen-bonding organocatalysts for asymmetric domino/cascade reactions. Adv. Synth. Catal. 357, 253-281 (2015).

38. Cheng, D.-J. et al. Highly enantioselective kinetic resolution of axially chiral BINAM derivatives catalyzed by a Brønsted acid. Angew. Chem. Int. Ed. Engl. 53, 3684-3687 (2014).

39. Lin, J.-S. et al. Brønsted acid catalyzed asymmetric hydroamination of alkenes: synthesis of pyrrolidines bearing a tetrasubstituted carbon stereocenter. Angew. Chem. Int. Ed. Engl. 54, 7847-7851 (2015).

40. Brandes, S., Bella, M., Kjærsgaard, A. \& Jørgensen, K. A. Chirally aminated 2-naphthols-organocatalytic synthesis of non-biaryl atropisomers by asymmetric Friedel-Crafts amination. Angew. Chem. Int. Ed. 45, 1147-1151 (2006).

41. Brandes, S. et al. Non-biaryl atropisomers in organocatalysis. Chem. Eur. J. 12, 6039 (2006).

42. Okino, T., Hoashi, Y. \& Takemoto, Y. Enantioselective Michael reaction of malonates to nitroolefins catalyzed by bifunctional organocatalysts. J. Am. Chem. Soc. 125, 12672-12673 (2003).

43. Peng, F. et al. Organocatalytic enantioselective Michael addition of 2,4-pentandione to nitroalkenes promoted by bifunctional thioureas with central and axial chiral elements. J. Org. Chem. 73, 5202 (2008).

44. Miyaura, N. \& Suzuki, A. Palladium-catalyzed cross-coupling reactions of organoboron compounds. Chem. Rev. 95, 2457-2483 (1995).

45. Bartoli, G., Bencivenni, G. \& Dalpozzo, R. Organocatalytic strategies for the asymmetric functionalization of indoles. Chem. Soc. Rev. 39, 4449-4465 (2010)

46. Dalpozzo, R. Strategies for the asymmetric functionalization of indoles: an update. Chem. Soc. Rev. 44, 742-778 (2015).

47. Qiao, Z. et al. An organocatalytic, $\delta$-regioselective, and highly enantioselective nucleophilic substitution of cyclic Morita-Baylis-Hillman alcohols with indoles. Angew. Chem. Int. Ed. 49, 7294-7298 (2010).

48. Akiyama, T., Itoh, J., Yokota, K. \& Fuchibe, K. Enantioselective Mannich-type reaction catalyzed by a chiral Brønsted acid. Angew. Chem. Int. Ed. 43, 1566-1568 (2004).

49. Uraguchi \& Terada, M. Chiral Brønsted acid-catalyzed direct Mannich reactions via electrophilic activation. J. Am. Chem. Soc. 126, 5356-5357 (2004)

50. Parmar, D., Sugiono, E., Raja, S. \& Rueping, M. Complete field guide to asymmetric BINOL-phosphate derived Brønsted acid and metal catalysis: history and classification by mode of activation; Brønsted acidity, hydrogen bonding, ion pairing, and metal phosphates. Chem. Rev. 114, 9047-9153 (2014).

51. Zhang, Z. \& Antilla, J. Enantioselective construction of pyrroloindolines catalyzed by chiral phosphoric acids: total synthesis of $(-)$-debromoflustramine B. Angew. Chem. Int. Ed. 51, 11778-11782 (2012).

52. Wang, S.-G., Yin, Q., Zhuo, C.-X. \& You, S.-L. Asymmetric dearomatization of $\beta$-naphthols through an amination reaction catalyzed by a chiral phosphoric acid. Angew. Chem. Int. Ed. 54, 647-650 (2015).

53. Kang, Q., Zhao, Z.-A. \& You, S.-L. Highly enantioselective Friedel - Crafts reaction of indoles with imines by a chiral phosphoric acid. J. Am. Chem. Soc. 129, 1484-1485 (2007).

54. You, S.-L., Cai, Q. \& Zeng, M. Chiral Brønsted acid catalyzed Friedel-Crafts alkylation reactions. Chem. Soc. Rev. 38, 2190-2201 (2009). 


\section{Acknowledgements}

We greatly appreciate the financial support from the National Natural Science Foundation of China (Nos 21572095 and 21572096). B.T. thanks the Thousand Young Talents Program for financial support. We sincerely dedicated this paper to professor Carlos F. Barbas III for a deep memory.

\section{Author contributions}

J.-W.Z. performed experiments. D.-J.C. took part in the initial reaction development. J.-H.X. and C.S. helped with characterizing all new compounds. B.T. and X.-Y.L. conceived and directed the project and wrote the paper.

\section{Additional information}

Accession codes: The X-ray crystallographic coordinates for structures reported in this Article have been deposited at the Cambridge Crystallographic Data Centre (CCDC), under deposition numbers CCDC 1439772 and CCDC 1440020. These data can be obtained free of charge from The Cambridge Crystallographic Data Centre via http:// www.ccdc.cam.ac.uk/data_request/cif.
Supplementary Information accompanies this paper at http://www.nature.com/ naturecommunications

Competing financial interests: The authors declare no competing financial interests.

Reprints and permission information is available online at http://npg.nature.com/ reprintsandpermissions/

How to cite this article: Zhang, J.-W. et al. Discovery and enantiocontrol of axially chiral urazoles via organocatalytic tyrosine click reaction. Nat. Commun. 7:10677 doi: 10.1038/ncomms10677 (2016).

(c) (i) This work is licensed under a Creative Commons Attribution 4.0 International License. The images or other third party material in this article are included in the article's Creative Commons license, unless indicated otherwise in the credit line; if the material is not included under the Creative Commons license, users will need to obtain permission from the license holder to reproduce the material. To view a copy of this license, visit http://creativecommons.org/licenses/by/4.0/ 